\title{
Long-term records of cadmium and silver contamination in sediments and oysters from the Gironde fluvial-estuarine continuum - Evidence of changing silver sources
}

\author{
Laurent Lanceleur $^{\mathrm{a}}$, Jörg Schäfer ${ }^{\mathrm{a}, *}$, Jean-François Chiffoleau ${ }^{\mathrm{b}}$, Gérard Blanc ${ }^{\mathrm{a}}$, Dominique Auger ${ }^{\mathrm{b}}$, \\ Sophie Renault ${ }^{\mathrm{c}}$, Magalie Baudrimont ${ }^{\mathrm{c}}$, Stéphane Audry ${ }^{\mathrm{d}}$ \\ a Université de Bordeaux, UMR 5805 EPOC, Av. des Facultés, 33405 Talence Cedex, France \\ b IFREMER Centre de Nantes, Département DCN/BE, BP 21105, 44311 Nantes Cedex 3, France \\ 'Université de Bordeaux, UMR 5805 EPOC, 2 Rue du Professeur Jolyet, 33120 Arcachon Cedex, France \\ ${ }^{\mathrm{d}}$ Université de Toulouse, UPS (OMP), LMTG, 14 Av. Edouard Belin, 31400 Toulouse, France
}

\section{A R T I C L E I N F O}

Article history:

Received 9 March 2011

Received in revised form 15 July 2011

Accepted 17 July 2011

Available online 24 August 2011

\section{Keywords:}

Silver

Cadmium

Estuary

Oyster

Biomonitoring

\begin{abstract}
A B S T R A C T
The Gironde fluvial estuarine system is impacted by historic metal pollution (e.g. Cd, $\mathrm{Zn}, \mathrm{Hg}$ ) and oysters (Crassostrea gigas) from the estuary mouth have shown extremely high Cd concentrations for decades. Based on recent work (Chiffoleau et al., 2005) revealing anomalously high Ag concentrations (up to $65 \mathrm{mg} \mathrm{kg}^{-1}$; dry weight) in Gironde oysters, we compared long-term ( 1955-2001) records of Ag and $\mathrm{Cd}$ concentrations in reservoir sediment with the respective concentrations in oysters collected between 1979 and 2010 to identify the origin and historical trend of the recently discovered Ag anomaly. Sediment cores from two reservoirs upstream and downstream from the main metal pollution source provided information on (i) geochemical background (upstream; $\mathrm{Ag}$ : $\sim 0.3 \mathrm{mg} \mathrm{kg}^{-1}$; $\mathrm{Cd}: \sim 0.8 \mathrm{mg} \mathrm{kg}^{-1}$ ) and (ii) historical trends in $\mathrm{Ag}$ and $\mathrm{Cd}$ pollution. The results showed parallel concentration-depth profiles of $\mathrm{Ag}$ and Cd supporting a common source and transport. Decreasing concentrations since 1986 (Cd: from 300 to $11 \mathrm{mg} \mathrm{kg}-1$; $\mathrm{Ag}$ : from 6.7 to $0.43 \mathrm{mg} \mathrm{kg}^{-1}$ ) reflected the termination of $\mathrm{Zn}$ ore treatment in the Decazeville basin followed by remediation actions. Accordingly, Cd concentrations in oysters decreased after 1988 (from 109 to $26 \mathrm{mg} \mathrm{kg}^{-1}$, dry weight (dw)), while Ag bioaccumulation increased from 38 up to $116 \mathrm{mg} \mathrm{kg}^{-1}$, dw after 1993. Based on the $\mathrm{Cd} / \mathrm{Ag}$ ratio $(\mathrm{Cd} / \mathrm{Ag} \sim 2)$ in oysters sampled before the termination of zinc ore treatment (1981-1985) and assuming that nearly all Cd in oysters originated from the metal point source, we estimated the respective contribution of $\mathrm{Ag}$ from this source to Ag concentrations in oysters. The evolution over the past 30 years clearly suggested that the recent, unexplained $\mathrm{Ag}$ concentrations in oysters are due to increasing contributions (>70\% after 1999) by other sources, such as photography, electronics and emerging $\mathrm{Ag}$ applications/materials.
\end{abstract}

(c) 2011 Elsevier Ltd. All rights reserved.

\section{Introduction}

The Gironde Estuary (Fig. 1) is known for its metal pollution since high Cd accumulation ( $>100 \mu \mathrm{g} \mathrm{g}^{-1}$, dry weight) in oysters (Crassotreas gigas) was discovered in the end of 1970s (e.g. Claisse, 1989) resulting in prohibition of consumption, production and purification of oysters since 1996 (e.g. Audry et al., 2004a). The main source of metal pollution was coal mining and Zn-ore treatment in the Decazeville watershed. Since the cessation of this metallurgical industry (1986), remediation and pollution management have clearly reduced Cd emission (Audry et al., 2004a). In the Gironde watershed, suspended particles are major vectors for $\mathrm{Cd}$, $\mathrm{Ag}$ and other metals (e.g. Audry et al., 2004a; Lanceleur et al.,

\footnotetext{
* Corresponding author. Tel.: +33 540002967; fax: +33 556880848

E-mail address: j.schaefer@epoc.u-bordeaux1.fr (J. Schäfer).
}

2011). Part of these particles accumulate in hydroelectric reservoirs, where the pollutants may be recycled (e.g. released to porewaters; Roulier et al., 2010) or stored over decades, providing sedimentary records of past pollutions (Valette-Silver, 1993; Audry et al., 2004b; Castelle et al., 2007). The hydroelectric reservoirs on the Lot River downstream from the Decazeville watershed contain huge sediment stocks with high metal loads $\left(9.47 \pm 0.9 \times 10^{6} \mathrm{~m}^{3}\right.$ of sediment containing approximately $200 \mathrm{t}$ of $\mathrm{Cd}$ ), that may be remobilized by floods, dredging and construction work (Audry et al., 2004a; Coynel et al., 2007). Although Cd has long been considered as the major pollutant, many other metals derived from the same source also show important anomalies in both sediment and water (e.g. Hg, Cu, Zn; Schäfer et al., 2006; Castelle et al., 2007). Furthermore, the regional geology and agricultural activities also contribute (e.g. As, $\mathrm{Cu}, \mathrm{Zn}$ ) to the metal/metalloid loads in the Gironde watershed (Masson et al., 2006, 2007). Recent work has 

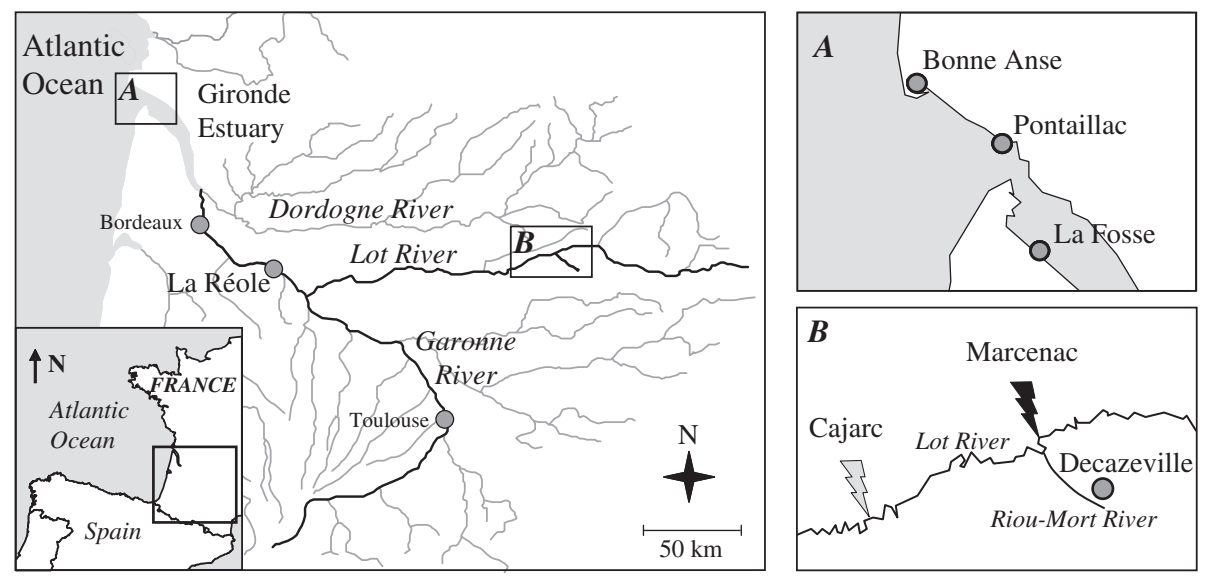

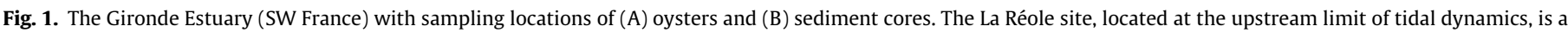
permanent observation site for trace element concentrations and fluxes at the main entry of the Gironde Estuary (for details see Schäfer et al., 2002).

revealed remarkably high $\mathrm{Ag}$ concentrations (up to $60 \mathrm{mg} \mathrm{kg}^{-1}$ in $2003 / 2004$ ) in wild oysters at the mouth of the Gironde Estuary (Fig. 1A; i.e. the highest measured in oysters and mussels along the French coast; Chiffoleau et al., 2005), indicating the fluvialestuarine system is also contaminated by Ag. Both $\mathrm{Ag}$ and $\mathrm{Cd}$ are highly toxic to aquatic organisms and may be easily bioaccumulated (Eisler, 1996; US EPA, 2001; Vijayavel et al., 2007), especially by oysters (e.g. Reinfelder et al., 1997; Gunther et al., 1999; Ivanina et al., 2011). The measured concentrations in the Gironde oysters clearly exceed safety limits for human consumption for $\mathrm{Cd}$ (5 mg kg-1; dw; EC No. 466/2001) and although there is no legal threshold for $\mathrm{Ag}$, consumption of oysters from several sites along the French coast (Chiffoleau et al., 2005) may be incompatible with human maximum $\mathrm{Ag}$ daily intake recommended by the EPA (0.005 $\mathrm{mg} \mathrm{kg}^{-1} \mathrm{~d}^{-1}$; www.epa.gov/iris/subst/0099.htm).

The present work aimed at documenting for the first time the historical $\mathrm{Ag}$ records in reservoir sediments upstream and downstream from the Decazeville watershed to (i) establish geochemical background for Ag in the upper Lot River watershed and (ii) quantify the extent of historical $\mathrm{Ag}$ contamination by the metal point source (Fig. 1B). Furthermore, we compare and discuss the chronologies of $\mathrm{Cd}$ and $\mathrm{Ag}$ accumulation in reservoir sediments and oysters from the Gironde watershed to understand (i) their relationships and (ii) changes over time in both concentrations and potential sources.

\section{Materials and methods}

\subsection{Study area}

The Gironde Estuary ( $170 \mathrm{~km}$ length; Fig. 1), draining a $80000 \mathrm{~km}^{2}$ watershed, is a major European estuary. Its mean annual freshwater discharge varies between 800 and $1000 \mathrm{~m}^{3} \mathrm{~s}^{-1}$, with typical water and particle residence times of $\sim 20-90 \mathrm{~d}$ and $\sim 1-2$ years, respectively (Sottolichio and Castaing, 1999). Suspended particulate matter (SPM) concentrations in its well developed Maximum Turbidity Zone (MTZ) frequently exceed $1 \mathrm{~g} \mathrm{~L}^{-1}$, making the Gironde Estuary one of the most turbid estuaries in Europe. A high number of studies on physical, hydrological and geochemical characteristics of the Gironde Estuary and its watershed (e.g. metal pollution) make it a model estuary, especially for understanding trace element transport and reactivity in impacted watersheds and macrotidal estuaries (e.g. Sottolichio and Castaing, 1999; Schäfer et al., 2002).

The main source of the historical metal pollution is located in the upper Lot River watershed, where a small tributary (i.e. the Riou Mort River) drains a waste area of a former zinc ore manufacturing facility (1842-1987) in the Decazeville basin (Fig. 1B). The metallurgical activity ended after a major pollution accident in 1986 followed by ongoing remediation efforts such as the treatment of drainage water and the confinement of a part of the waste deposits in storage basins (1987). However, the major part of the metallurgical waste is still exposed to atmospheric agents, i.e. leaching and erosion continue (e.g. Audry et al., 2004b).

\subsection{Core retrieval and sampling}

Reservoir sediments usually accumulate at high rates (typically $>2 \mathrm{~cm}_{\text {year }}{ }^{-1}$; e.g. Müller et al., 2000; Audry et al., 2004b) and consequently are considered as being little affected by early diagenesis processes, i.e. providing preserved records of historical inputs (Callender, 2000). In June 2001, sediment cores (0-140 cm depth) were collected in two hydroelectric reservoirs on the Lot River, upstream (Marcenac) and downstream (Cajarc) from the pollution source (Fig. 1B) as described elsewhere (Audry et al., 2004b). Briefly, horizontal sections of the cores were sliced, dried at $50{ }^{\circ} \mathrm{C}$ to constant weight, powdered and homogenised with an agate mortar and stored in the dark awaiting analyses.

\subsection{Bioindicator sampling}

As suspension-feeding bivalves, oysters are exposed to both dissolved metals and metals bound to mineral particles, phytoplankton and organic matter. Their capacity to accumulate both Ag and Cd from their environment (e.g. Gunther et al., 1999; Baudrimont et al., 2005) makes them good bioaccumulators for monitoring studies. Within the National Network for the Observation of Marine Environment Quality (RNO/ROCCH; i.e. the French MusselWatch; http://www.ifremer.fr/deltn/pages/rno.htm), 2-year old wild-growing Japanese oysters (Crassostrea gigas) were collected according to the guidelines for monitoring contaminants in biota defined by the OSPAR commission (http://www.ospar.org). Three sites at the mouth of the Gironde Estuary (Fig. 1A) have been sampled four times a year during 1979-2002, twice a year from 2003 to 2007 (February and November) and annually (February) since 2008. The sampling sites are located in the downstream part of the Gironde Estuary dominated by marine sand and gravel with some shell fragments (Larrose et al., 2010). Wild oyster banks at the Bonne Anse and La Fosse sites are surrounded by silty/sandy sediment, whereas at Pontaillac they are close to rocky outcrops (calcareous cliffs). The three sites are representative of different salinity ranges with typical salinity ranges being 25-30 at the Bonne Anse site, 20-25 at the Pontaillac site and 15-20 at the La Fosse site. 


\subsection{Analyses}

All the labware used was acid cleaned $\left(\mathrm{HNO}_{3}\right.$ analytical grade; $10 \% ; 72 \mathrm{~h}$ ), thoroughly rinsed with Milli-Q water, dried under a laminar flow hood and stored in double sealed polyethylene bags prior to use. For the determination of total trace element concentrations in reservoir sediments, representative sub-samples (30 mg of dry, powdered and homogenised material) were digested in acidcleaned PP-tubes (DigiTUBEs ${ }^{\circledR}, \mathrm{SCP}$ SCIENCE) using $1.5 \mathrm{~mL} \mathrm{HCl}$ (12 M, Plasmapur), $0.5 \mathrm{~mL} \mathrm{HNO}_{3}$ (14 M, Plasmapur) and $2 \mathrm{~mL} \mathrm{HF}$ (26 M, Plasmapur) at $110^{\circ} \mathrm{C}$ for $2 \mathrm{~h}$ in a temperature-controlled digestion system (DigiPREP MS ${ }^{\circledR}$, SCP SCIENCE). After complete cooling, the digestate was evaporated to dryness, then the residue was dissolved using $150 \mu \mathrm{LNNO}_{3}$ (12 M, Plasmapur), brought to $10 \mathrm{~mL}$ with double deionized Milli-Q water and stored in the dark at $4{ }^{\circ} \mathrm{C}$ awaiting analysis (adapted from Schäfer and Blanc, 2002; Audry et al., 2004a). The Cajarc core was ${ }^{137}$ Cs-dated using a low background noise $\gamma$-ray spectrometer with Ge detector (Intertechnique EGSP 2200-25; Audry et al., 2004b). Cadmium and Ag bioaccumulation in oysters was measured from aliquots $(200 \mathrm{mg})$ of freeze-dried samples digested at $90{ }^{\circ} \mathrm{C}$ with $\mathrm{HNO}_{3}$ for $\mathrm{Cd}$ and a mixture of $\mathrm{HNO}_{3}$ and $\mathrm{HCl}$ for $\mathrm{Ag}$ as described elsewhere (Chiffoleau et al., 2005).

Cadmium and $\mathrm{Ag}$ concentrations in the sediment digestates were measured by ICP-MS (X7, Thermo-Fisher) at EPOC, Bordeaux 1 University. Precision, evaluated from parallel analyses of international certified reference materials (NCS-DC-70317, NCS-DC-70311), was $<5 \%$ (rsd) and results were consistently within the certified ranges (Table 1; Audry et al., 2004b; Lanceleur et al., 2011).

Cadmium and $\mathrm{Ag}$ concentrations in oyster digestates were determined at Ifremer, Centre de Nantes by graphite furnace atomic absorption spectrometry (AA800, Varian) using the Zeeman background correction for non-specific absorption. Quality control was satisfactorily performed by analyses of CRM (CRM TORT-2, CRM DOLT-2, SRM 1566b; Table 1; Chiffoleau et al., 2005) and through regularly successful participations in QUASIMEME (Quality Assurance of Information for Marine Environmental Monitoring in Europe) intercalibration exercises.

Flux estimates of particulate $\mathrm{Cd}$ and $\mathrm{Ag}$ gross fluxes (fluvial fluxes into the estuary) at the La Réole site, i.e. the main fluvial entry of the Gironde Estuary were performed from daily discharge and SPM (suspended particulate matter) data and monthly measured metal concentrations using commonly applied methods described in detail elsewhere (e.g. Schäfer et al., 2002; Audry et al., 2004a; Masson et al., 2007). The particulate Ag fluxes for the 1990-1998 period (no Ag data available) were estimated from the SPM fluxes (Schäfer et al., 2002) and using a particulate Ag concentration of $1.0 \mathrm{mg} \mathrm{kg}^{-1}$, i.e. the mean particulate $\mathrm{Ag}$ concentration measured during the last decade at the La Réole site (Lanceleur et al., 2011).

\section{Results}

\subsection{Ag and Cd concentrations in sediment cores}

At the Marcenac site, which served as a reference site for the geochemical background of the upper Lot River watershed (Audry et al., 2004b), concentrations (mean \pm SD) were low and rather constant, i.e. $0.31 \pm 0.06 \mathrm{mg} \mathrm{kg}^{-1}$ for $\mathrm{Ag}$ and $0.77 \pm 0.22 \mathrm{mg} \mathrm{kg}^{-1}$ for $\mathrm{Cd}$ (Fig. 2). In the Cajarc sediment, directly affected by the former industrial activity in the Decazeville watershed (e.g. Audry et al., 2004b; Castelle et al., 2007), Ag concentrations ranged from 0.43 to $6.96 \mathrm{mg} \mathrm{kg}^{-1}$ and were correlated with $\mathrm{Cd}$ concentrations $\left(R_{\text {Spearman }}=0.90 ; n=43 ; p<0.01\right)$. Concentrations of both $\mathrm{Ag}$ and $\mathrm{Cd}$ decreased from the $42 \mathrm{~cm}$ depth to the surface $(\mathrm{Cd}$ : from 300 to $11 \mathrm{mg} \mathrm{kg}^{-1}$; $\mathrm{Ag}$ : from 6.7 to $0.43 \mathrm{mg} \mathrm{kg}^{-1}$ ), corresponding to the $1986-2001$ period according to ${ }^{137} \mathrm{Cs}$ records (Fig. 2). Normalisation of metal concentrations by Sc presented in previous work showed that grain size variations had a negligible impact on the historical metal record (Audry et al., 2004b).

\section{2. $\mathrm{Ag}$ and $\mathrm{Cd}$ concentrations in oysters}

Total metal concentrations in oysters, expressed as $\mathrm{mg} \mathrm{kg}^{-1}$ dry weight ( $\mathrm{dw}$ ) of oyster tissue, undergo seasonal variations due to weight gains and losses during the reproduction cycle (Fig. 3A and B; Páez-Osuna et al., 1995). In order to (1) limit scattering induced by seasonal environmental parameters on oyster life cycles and (ii) account for different sampling frequencies (see sampling section) we used only the February data obtained during the whole observation period for the comparison of historical data with recent values (Fig. 3C-G).

Oysters from the La Fosse site (the most upstream site) showed systematically higher concentrations in both $\mathrm{Cd}$ and $\mathrm{Ag}$, while the lowest concentrations occurred at the Bonne Anse site (Fig. 3C and D). Cadmium concentrations in oysters at the La Fosse site decreased after 1988 from 109 to $26 \mathrm{mg} \mathrm{kg}^{-1}$, dw, while Ag bioaccumulation increased from 38 to $116 \mathrm{mg} \mathrm{kg}^{-1}$, dw, after 1993 (Fig. 3C and $\mathrm{D}$ ). Although being clearly lower, the $\mathrm{Cd}$ and $\mathrm{Ag}$ concentrations at the other sites showed similar trends. Compared to the La Fosse site, the $\mathrm{Cd}$ and Ag concentrations at the Pontaillac and the Bonne Anse sites were respectively equivalent to $54 \pm 11 \%$ for $\mathrm{Cd}$ and $78 \pm 18 \%$ for $\mathrm{Ag}$ and $31 \pm 10 \%$ for $\mathrm{Cd}$ and $38 \pm 16 \%$ for $\mathrm{Ag}$.

\section{Discussion}

\subsection{Geochemical background and historical record of $\mathrm{Cd}$ and $\mathrm{Ag}$ in river sediment}

The historical metal records in the Cajarc sediments closely reflect the evolution of the industrial activity in the source area from the 1950s to present, including termination of the $\mathrm{Zn}$ extraction in 1986 and subsequent remediation (Audry et al., 2004b; Castelle et al., 2007). The geochemical background values of the upstream Lot River watershed estimated from the Marcenac values (Cd: $0.77 \mathrm{mg} \mathrm{kg}^{-1}$; and $\mathrm{Ag}$ : $0.30 \mathrm{mg} \mathrm{kg}^{-1}$ ) were $15-384$ and $1.4-23$ times lower, respectively, than $\mathrm{Cd}$ and $\mathrm{Ag}$ concentrations at the contaminated Cajarc site. Co-evolution of $\mathrm{Cd}$ and Ag concentration-depth profiles supports common source and transport, suggesting that the Decazeville basin formerly was an important Ag source to the Lot-Garonne-Gironde fluvial estuarine continuum (Fig. 2). The observed Ag concentrations in the Lot River sediments were of similar magnitude as those reported for polluted English

Table 1

Results obtained from analyses of certified reference materials. $n$ : number of independent analyses.

\begin{tabular}{|c|c|c|c|c|c|c|}
\hline \multirow[t]{2}{*}{ Reference material } & \multirow[t]{2}{*}{ Description } & \multirow[t]{2}{*}{$n$} & \multicolumn{2}{|c|}{$\mathrm{Ag}\left(\mathrm{mg} \mathrm{kg}^{-1}, \mathrm{dw}\right)$} & \multicolumn{2}{|c|}{$\mathrm{Cd}\left(\mathrm{mg} \mathrm{kg}^{-1}, \mathrm{dw}\right)$} \\
\hline & & & Certified value & Measured value & Certified value & Measured value \\
\hline NCS-DC-70311 & River sediment & 5 & $6.73 \pm 0.62$ & $6.28 \pm 0.38$ & $3.76 \pm 0.23$ & $3.66 \pm 0.10$ \\
\hline NCS-DC-70317 & River sediment & 5 & $0.32 \pm 0.02$ & $0.34 \pm 0.01$ & $0.57 \pm 0.04$ & $0.55 \pm 0.02$ \\
\hline SRM-1566b & Oyster tissue & 47 & $0.67 \pm 0.01$ & $0.61 \pm 0.04$ & $2.48 \pm 0.08$ & $2.41 \pm 0.09$ \\
\hline CRM-278 & Mussel tissue & 6 & - & $0.20 \pm 0.04$ & $0.35 \pm 0.01$ & $0.33 \pm 0.02$ \\
\hline
\end{tabular}




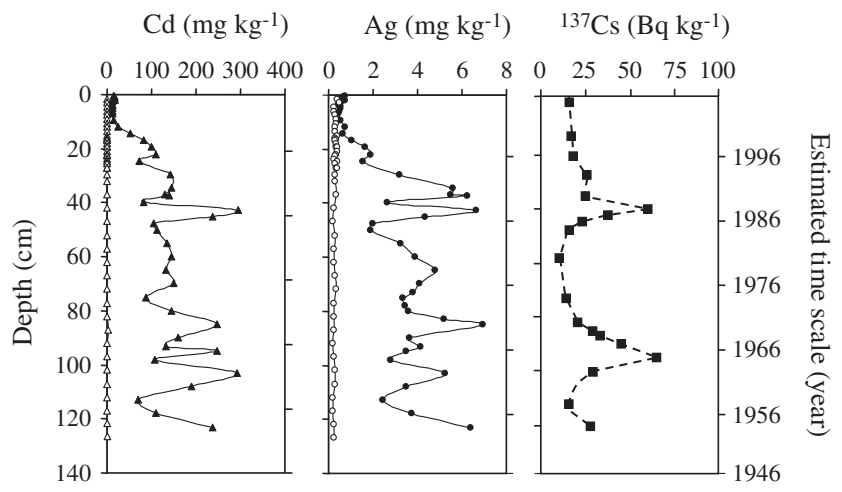

Fig. 2. Cadmium concentrations, Ag concentrations and ${ }^{137} \mathrm{Cs}$ activity vs depth for the sediment cores from the Marcenac (geochemical background; empty symbols) and the Cajarc (historical record of metallurgical pollution; filled symbols) sites. Cadmium and ${ }^{137}$ Cs profiles are from Audry et al. (2004b).

estuaries (up to $5 \mathrm{mg} \mathrm{kg}^{-1}$ with $0.1 \mathrm{mg} \mathrm{kg}^{-1}$ as the background concentration; Bryan, 1984). As in many industrially affected aquatic systems at the global scale, metal stocks in the contaminated Lot River sediments are of great concern for the Gironde fluvioestuarine system due to their possible remobilisation during floods (e.g. Coynel et al., 2007), dredging (e.g. Audry et al., 2004a), passive diffusion at the water-sediment interface, (e.g. Rivera-Duarte and Flegal, 1997; Van Den Berg et al., 1999) or bioturbation (e.g. Zoumis et al., 2001).

\subsection{Bioavailability of $\mathrm{Cd}$ and $\mathrm{Ag}$ to oysters}

The concentration gradient of $\mathrm{Cd}$ and $\mathrm{Ag}$ in oysters from the $\mathrm{La}$ Fosse site to the Bonne Anse site, i.e. decreasing concentrations from upstream to downstream, could be explained by differences in exposure. Exposure of oysters to dissolved metals results in direct uptake (direct pathway) and is considered the major contamination pathway for both Cd (e.g. Ettajani et al., 2001) and Ag (e.g. Abbe and Sanders, 1990). In estuarine salinity gradients, both dissolved Cd and Ag typically show highest concentrations in the 15-20 salinity range (e.g. Dabrin et al., 2009; Tappin et al., 2010) due to desorption from the particulate phase by chloride-complexation (e.g. Turner et al., 1993; Luoma et al., 1995). Fluvial Cd and Ag transport into the Gironde Estuary mainly occurs in the particulate phase (respectively 80\% and 96\%; Schäfer et al., 2002; Lanceleur et al., 2011). Their addition to the dissolved phase results in the typical 'bell-shaped' distribution of dissolved Cd (e.g. Dabrin et al., 2009) and Ag (Lanceleur et al., unpublished; Tappin et al., 2010) along the estuarine salinity gradient. In the Gironde Estuary, dissolved $\mathrm{Cd}$ and $\mathrm{Ag}$ concentrations decrease from respectively 150-170 ng L $\mathrm{L}^{-1}$ and $6-8 \mathrm{ng} \mathrm{L}^{-1}$ in the $15-20$ salinity range towards the seaward end due to dilution by oceanic water (Atlantic Ocean: $\mathrm{Cd}_{\mathrm{D}}=4 \pm 3 \mathrm{ng} \mathrm{L}^{-1}$; Kremling, 1985; North Atlantic Ocean: $\mathrm{Ag}_{\mathrm{D}}=0.39 \mathrm{ng} \mathrm{L}^{-1}$; Rivera-Duarte et al., 1999). This may induce systematic spatial differences in oyster exposure with decreasing concentrations from the La Fosse to the Bonne Anse site (Figs. 1 and 3). During the whole observed period, concentrations in oysters from the Pontaillac site were lower than those in La Fosse oysters, i.e. by $46 \pm 11 \%$ for Cd and $22 \pm 18 \%$ for Ag (with metal concentrations at La Fosse being set equal to 100\%). Accordingly, relative (compared to the La Fosse site) metal accumulation at the Pontaillac site (i.e. at higher salinity) appeared significantly higher for Ag than for Cd $(p<0.001$; Log transformation of data followed by a one-way ANOVA). Similarly, but to a lesser extent, the relative metal accumulation at Bonne Anse was significantly higher $(p<0.001)$ for $\mathrm{Ag}(38 \pm 16 \%)$ than for $\mathrm{Cd}(31 \pm 10 \%)$. Further work is necessary to understand if these differences are due to (i) differences in the slopes of dissolved $\mathrm{Cd}$ and $\mathrm{Ag}$ distribution in the high salinity range, i.e. the fact that maximum $\mathrm{Ag}$ release from particles occurs at higher salinities than for $\mathrm{Cd}$ as it was shown experimentally (Ciffroy et al., 2003) and/or (ii) different assimilation efficiencies for $\mathrm{Cd}$ and $\mathrm{Ag}$ species. In fact, compared to $\mathrm{Cd}$, data on dissolved $\mathrm{Ag}$ distribution and speciation along estuarine salinity gradients are extremely scarce, i.e. inexistent for most estuaries. From recent maximum dissolved $\mathrm{Cd}\left(170 \mathrm{ng} \mathrm{L}^{-1}\right)$ and $\mathrm{Ag}\left(8 \mathrm{ng} \mathrm{L}^{-1}\right)$ concentrations in the Gironde Estuary salinity gradient $(S=15-20$; Dabrin et al., 2009; Lanceleur et al., unpublished) and the respective concentrations in oysters from the La Fosse site (Cd: $\sim 30 \mathrm{mg} \mathrm{kg}^{-1}$, dw; Ag: $\left.\sim 80 \mathrm{mg} \mathrm{kg}^{-1}, \mathrm{dw}\right)$, we estimated minimum bioaccumulation factors (concentration in oysters/concentration in water) at $0.18 \times 10^{6}$ for $\mathrm{Cd}$ and $10 \times 10^{6}$ for $\mathrm{Ag}$. This suggests that in the Gironde Estuary oysters bioaccumulation factors are $\sim 55$ times higher for $\mathrm{Ag}$ than for $\mathrm{Cd}$. These results are consistent with previous experimental work showing that even if assimilation efficiency by trophic transfer in oysters is higher for Cd (C. virginica) than for Ag (Reinfelder et al., 1997), Ag-chlorocomplexes play an important role in $\mathrm{Ag}$ accumulation via the direct pathway by oysters compared to Cd (Engel et al., 1981), making Ag the strongest accumulated trace metal for certain marine bivalves (e.g. Luoma et al., 1995).

\subsection{Comparison of particulate $\mathrm{Cd}$ and Ag fluvial gross fluxes to the Gironde Estuary with Cd and Ag accumulation in oysters}

The Garonne River (the La Réole site; Fig. 1) is the main fluvial entry of particles and associated metals transported to the Gironde Estuary with $>80 \%$ (Cd; Schäfer et al., 2002) and $~ 96 \%$ ( Ag; Lanceleur et al., 2011) of the fluvial gross fluxes (i.e. fluvial fluxes to the estuary) occurring in the particulate phase. The evolution over time of Cd and Ag annual gross fluxes to the Gironde Estuary reflects (i) decreasing emissions in the historic source area (i.e. the Decazeville watershed) and (ii) the hydrological variability (e.g. Schäfer et al., 2002). Accordingly, Cd particulate gross fluxes at the La Réole site globally decreased by a factor of $\sim 4$ over the last two decades and may explain the parallel decrease in Cd concentrations in La Fosse oysters (from 95 to $25 \mathrm{mg} \mathrm{kg}^{-1}$, dw; Fig. 3E). Similar to $\mathrm{Cd}$, the estimated particulate Ag gross fluxes also tended to decrease during 1992-2009 by a factor of $\sim 4$ (Fig. 3F). In contrast to $\mathrm{Cd}, \mathrm{Ag}$ concentrations in oysters were at maximum during 1998-2003 and their evolution over time did not reflect that of the estimated Ag gross fluxes (Fig. 3F). This shows that after 1993 the fluvial Ag gross fluxes cannot explain the evolution of Ag bioaccumulation in oysters.

\subsection{Historical trend of $\mathrm{Ag}$ and Cd pollution}

Based on the observation that the $\mathrm{Cd} / \mathrm{Ag}$ ratio in oysters from the La Fosse site was constant before the termination of $\mathrm{Zn}$ ore treatment in the Decazeville basin $(\mathrm{Cd} / \mathrm{Ag}=2 \pm 0.4$; 1981-1985) and assuming that during the whole observation period nearly all $\mathrm{Cd}$ in oysters was derived from the metal point source, we estimated the respective (theoretical) $\mathrm{Ag}$ concentrations in oysters over time (Fig. 3G). The latter assumption is based on mass balances at the watershed scale, showing that even 13-16 years after the termination of zinc ore treatment (i.e. 1999-2002), the Decazeville basin contributed more than $61 \%-92 \%$ of total $\mathrm{Cd}$ fluxes into the Gironde Estuary (Masson et al., 2006). This is further supported by (i) historical records of $\mathrm{Cd}$ in estuarine freshwater sediments, reflecting the industrial activity in the Decazeville watershed (Grousset et al., 1999) and (ii) mass balances at the estuary scale, suggesting that intra-estuarine sources (e.g. the Bordeaux agglomeration) are negligible, compared to the main 


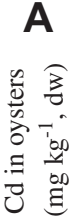

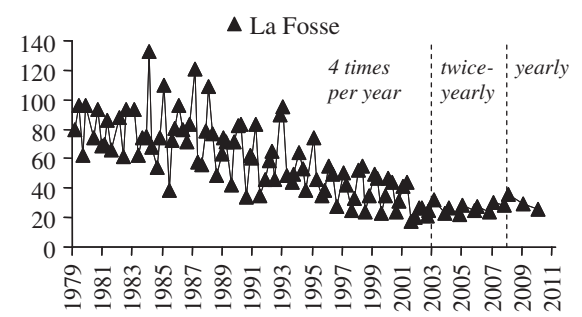

Time

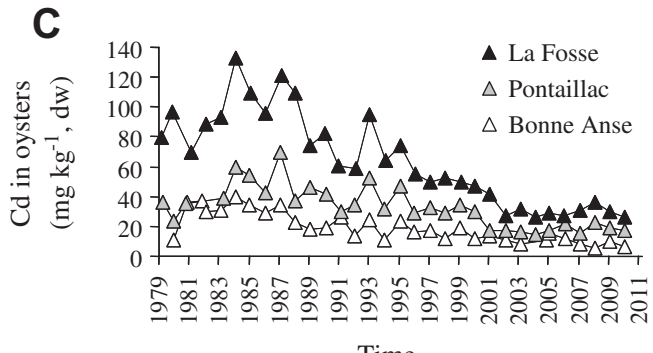

E

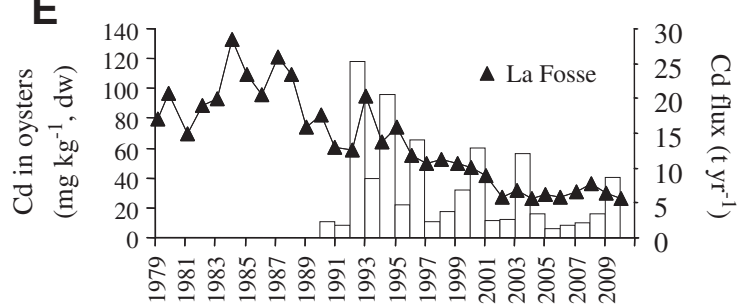

Time
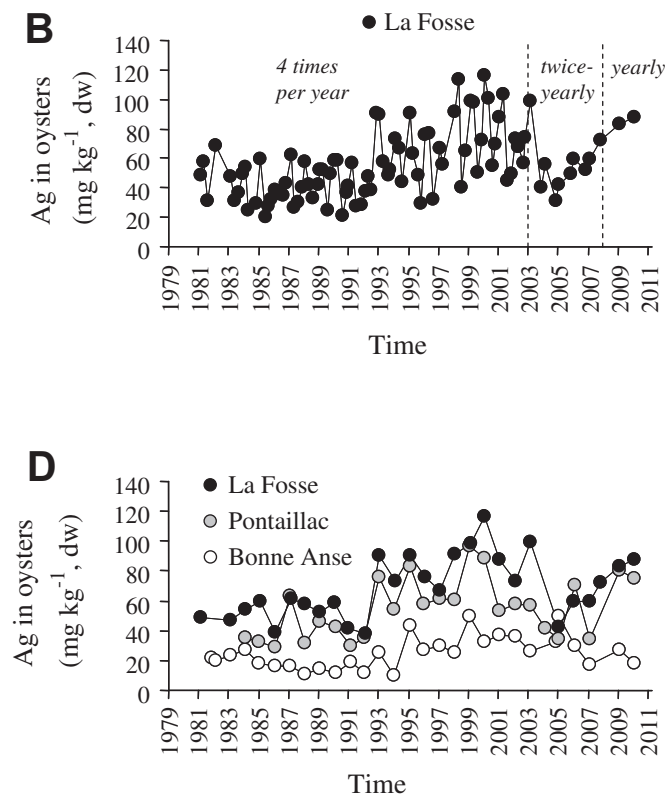

F

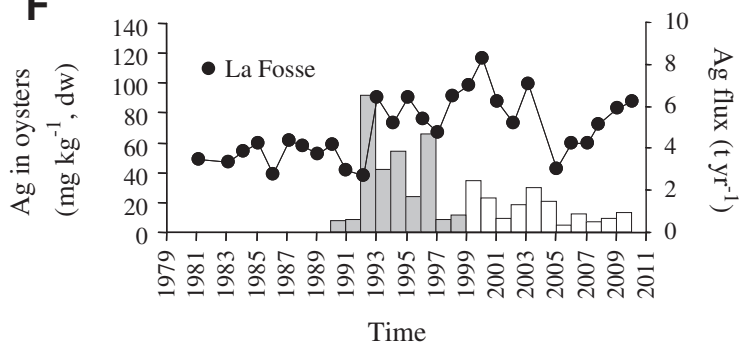

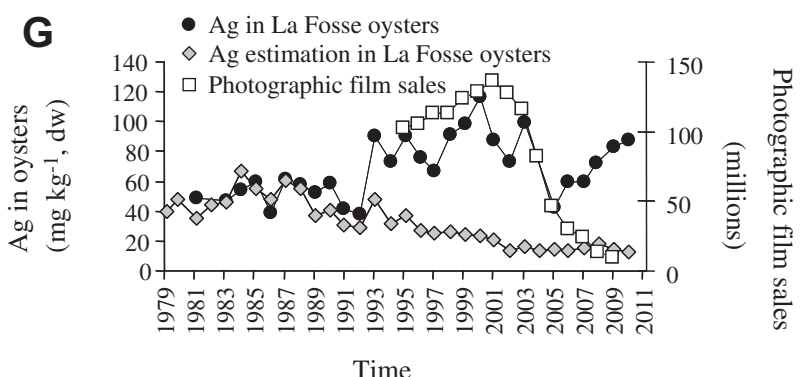

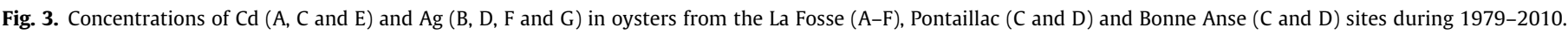

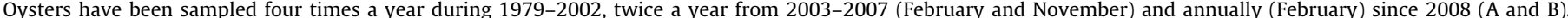

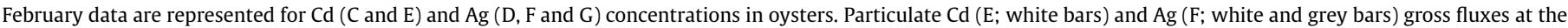

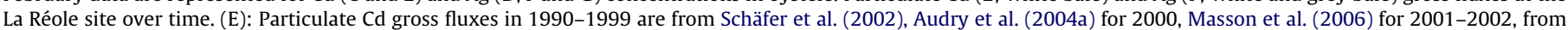

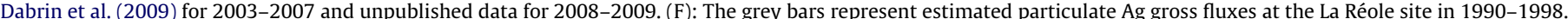

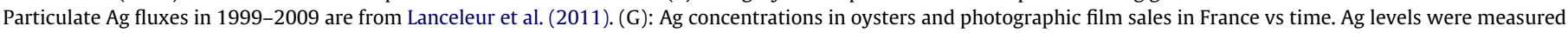
(full circles) and estimated (open squares) from pre-1986 Cd/Ag ratio and from Cd concentrations in oysters.

source (e.g. Schäfer et al., 2002; Audry et al., 2007; Dabrin et al., 2009).

Comparing the estimated theoretical Ag concentrations to the measured data suggests that before $\sim 1993, \mathrm{Ag}$ in the oysters from La Fosse was mostly derived from the Decazeville basin (Fig. 3G). In contrast, increasing Ag concentrations after 1993 were attributed to increasing contributions ( $>70 \%$ after 1999 ) by other sources. While soil erosion is the main natural Ag source to rivers, there are various anthropogenic Ag sources such as coal combustion, smelting, photography manufacturing and development, urban runoff, sewage treatment plants, cloud seeding and electrical supplies (e.g. US PHS, 1990; Purcell and Peters, 1998; Lanceleur et al.,
2011). In 1986, photography accounted for $45 \%$ of $\mathrm{Ag}$ demand in the United States (US PHS 1990) and greatly contributed to the Ag contamination of San Francisco Bay sediment, water and biota until the mid 1980s (Flegal et al., 2007). In France, photographic film sales increased from 103 to 136 million in 1995-2001 and decreased to 24 million in 2007 and 9 million in 2009, due to the development of numeric photography (Fig. 3G; data from the French Observatory for Imaging Professions OPI, 2010). Even if Ag load in oysters from the La Fosse site apparently followed this trend during 1995-2005, concentrations tended to increase after 2005 (Fig. 3G). Future work should aim at quantifying the contribution of recent increases in silver-containing paper sales 
(+21\% between 2006 and 2007; OPI, 2010), electronic products and emerging sources, e.g. growing use of $\mathrm{Ag}$ nanoparticles (e.g. Blaser et al., 2008).

\section{Conclusion}

Anomalously high $\mathrm{Cd}$ and $\mathrm{Ag}$ concentrations, up to 384 and 23 times higher than the respective regional background concentrations of $0.77 \mathrm{mg} \mathrm{kg}^{-1}(\mathrm{Cd})$ and $0.30 \mathrm{mg} \mathrm{kg}^{-1}(\mathrm{Ag})$ in the Lot River sediments downstream from the Decazeville watershed showed that $\mathrm{Ag}$ is a historical pollutant in the Gironde fluvial-estuarine system. The decreasing $\mathrm{Cd}$ concentrations in sediments since the end of the metallurgical activity in 1986 and the evolution of fluvial particulate Cd gross fluxes, fully explain the decreasing Cd concentrations in oysters from the estuary mouth. In contrast, neither the historical $\mathrm{Ag}$ record in river sediments nor the fluvial Ag gross fluxes can explain the recent increase in Ag concentrations in oysters, clearly suggesting increasing contributions (>70\% after 1999) by other, probably intra-estuarine sources. The observed gradients in $\mathrm{Cd}$ and $\mathrm{Ag}$ concentrations in oysters from the three sites near the estuary mouth probably reflect exposure to dissolved $\mathrm{Cd}$ and $\mathrm{Ag}$ concentrations, i.e. their typical distribution along the estuarine salinity gradient. Further work is necessary to identify these recent $\mathrm{Ag}$ sources and to understand their role in the estuarine Ag cycle and in Ag contamination of aquatic organisms.

\section{Acknowledgements}

The authors greatly acknowledge the thoughtful comments by two anonymous reviewers and Prof. Dr. M. Oehme. This work was supported by the French National Research Agency ANR "Vulnérabilité, Milieu et Climat" (ANR-07-VULN-003), the Agence de l'Eau Adour-Garonne and the "Ministère de l'Écologie, de l'Énergie, du Développement durable et de la Mer".

\section{References}

Abbe, G.R., Sanders, J.G., 1990. Pathways of silver uptake and accumulation by the American oyster (Crassostrea virginica) in Chesapeake Bay. Estuar. Coast. Shelf Sci. 31, 113-123.

Audry, S., Schäfer, J., Blanc, G., Bossy, C., Lavaux, G., 2004a. Anthropogenic components of heavy metal $(\mathrm{Cd}, \mathrm{Zn}, \mathrm{Cu}, \mathrm{Pb})$ budgets in the Lot-Garonne fluvial system (France). Appl. Geochem. 19, 769-786.

Audry, S., Schäfer, J., Blanc, G., Jouanneau, J.-M., 2004b. Fifty-year sedimentary record of heavy metal pollution $(\mathrm{Cd}, \mathrm{Zn}, \mathrm{Cu}, \mathrm{Pb})$ in the Lot River reservoirs (France). Environ. Pollut. 132, 413-426.

Audry, S., Blanc, G., Schäfer, J., Guérin, F., Masson, M., Robert, S., 2007. Budgets of $\mathrm{Mn}, \mathrm{Cd}$ and $\mathrm{Cu}$ in the macrotidal Gironde estuary (SW France). Mar. Chem. 107, 433-448.

Baudrimont, M., Schäfer, J., Marie, V., Maury-Brachet, R., Bossy, C., Boudou, A., Blanc, G., 2005. Geochemical survey and metal bioaccumulation of three bivalve species (Crassostrea gigas, Cerastoderma edule and Ruditapes philippinarum) in the Nord Médoc salt marshes (Gironde estuary, France). Sci. Total Environ. 337 $265-280$.

Blaser, S.A., Scheringer, M., MacLeod, M., Hungerbuhler, K., 2008. Estimation of cumulative aquatic exposure and risk due to silver: contribution of nanofunctionalized plastics and textiles. Sci. Total Environ. 390, 396-409.

Bryan, G.W., 1984. Pollution due to heavy metals and their compounds. In: Kinne, O. (Ed.), Marine Ecology: a Comprehensive, Integrated Treatise on Life in Oceans and Coastal Waters: Five. Ocean Management: Three. Pollution and Protection of the Seas, Radioactive Materials, Heavy Metals and Oil. John Wiley and Sons Ltd., New York, USA, pp. 1289-1431.

Callender, E., 2000. Geochemical effects of rapid sedimentation in aquatic systems: minimal diagenesis and the preservation of historical metal signatures. J. Paleolimnol. 23, 243-260.

Castelle, S., Schäfer, J., Blanc, G., Audry, S., Etcheber, H., Lissalde, J.-P., 2007. Fiftyyear record and solid state speciation of mercury in natural and contaminated reservoir sediment. Appl. Geochem. 22, 1359-1370.

Chiffoleau, J.-F., Auger, D., Roux, N., Rozuel, E., Santini, A., 2005. Distribution of silver in mussels and oysters along the French coasts: data from the national monitoring program. Mar. Pollut. Bull. 50, 1719-1723.

Ciffroy, P., Garnier, J.-M., Benyahya, L., 2003. Kinetic partitioning of Co, Mn, Cs, Fe, Ag, $\mathrm{Zn}$ and $\mathrm{Cd}$ in fresh waters (Loire) mixed with brackish waters (Loire estuary): experimental and modelling approaches. Mar. Pollut. Bull. 46, 626-641.
Claisse, D., 1989. Chemical contamination of French coasts. The results 10 years mussel watch. Mar. Pollut. Bull. 20, 523-528.

Coynel, A., Schäfer, J., Blanc, G., Bossy, C., 2007. Scenario of particulate trace metal and metalloid transport during a major flood event inferred from transient geochemical signals. Appl. Geochem. 22, 821-836.

Dabrin, A., Schäfer, J., Blanc, G., Strady, E., Masson, M., Bossy, C., Castelle, S., Girardot N., Coynel, A., 2009. Improving estuarine net flux estimates for dissolved cadmium export at the annual timescale: application to the Gironde Estuary. Estuar. Coast. Shelf Sci. 84, 429-439.

Eisler, R., 1996. Silver hazards to fish, wildlife, and invertebrates: a synoptic review. Contaminant Hazard Reviews, Report No.32.

Engel, D.W., Sunda, W.G., Fowler, B.A., 1981. Factors affecting trace metal uptake and toxicity to estuarine organisms. In: Vernberg, F., Calabrese, A., Thurberg F.P., Vernberg, W.B. (Eds.), Environmental parameters: Biological Monitoring of Marine Pollutants, New York, USA, pp. 127-144.

Ettajani, H., Berthet, B., Amiard, J.C., Chevolot, L., 2001. Determination of cadmium partitioning in microalgae and oysters: contribution to the assessment of trophic transfer. Arch. Environ. Contam. Toxicol. 40, 209-221.

Flegal, A.R., Brown, C.L., Squire, S., Ross, J.R.M., Scelfo, G.M., Hibdon, S., 2007. Spatial and temporal variations in silver contamination and toxicity in San Francisco Bay. Environ. Res. 105, 34-52.

Grousset, F., Jouanneau, J.M., Castaing, P., Lavaux, G., Latouche, C., 1999. A 70 year record of contamination from industrial activity along the Garonne River and its tributaries (SW France). Estuar. Coast. Shelf Sci. 48, 401-414.

Gunther, A.J., Davis, J.A., Hardin, D.D., Gold, J., Bell, D., Crick, J.R., Scelfo, G.M., Sericano, J., Stephenson, M., 1999. Long-term bioaccumulation monitoring with transplanted bivalves in the San Francisco Estuary. Mar. Pollut. Bull. 38, 170181.

Ivanina, A.V., Froelich, B., Williams, T., Sokolov, E.P., Oliver, J.D., Sokolova, I.M., 2011 Interactive effects of cadmium and hypoxia on metabolic responses and bacterial loads of eastern oysters Crassostrea virginica Gmelin. Chemosphere 82, 377-389.

Kremling, K., 1985. The distribution of cadmium, copper, nickel, manganese, and aluminium in surface waters of the open Atlantic and European shelf area. Deep-Sea Res. 32, 531-555.

Lanceleur, L., Schäfer, J., Bossy, C., Coynel, A., Larrose, A., Masson, M., Blanc, G., 2011. Silver fluxes to the Gironde Estuary - 11 years (1999-2009) of monitoring at the watershed scale. Appl. Geochem. 26, 797-808.

Larrose, A., Coynel, A., Schäfer, J., Blanc, G., Masse, L., Maneux, E., 2010. Assessing the current state of the Gironde estuary by mapping priority contaminant distribution and risk potential in surface sediment. Appl. Geochem. 25, 19121923.

Luoma, S.N., Ho, Y.B., Bryan, G.W., 1995. Fate, bioavailability and toxicity of Ag in estuarine environments. Mar. Pollut. Bull. 31, 44-54.

Masson, M., Blanc, G., Schäfer, J., 2006. Geochemical signals and source contributions to heavy metal $(\mathrm{Cd}, \mathrm{Zn}, \mathrm{Pb}, \mathrm{Cu})$ fluxes into the Gironde Estuary via its major tributaries. Sci. Total Environ. 370, 133-146.

Masson, M., Schäfer, J., Blanc, G., Anschutz, P., 2007. Seasonal variations and annual fluxes of arsenic in the Garonne, Dordogne and Isle Rivers, France. Sci. Total Environ. 373, 196-207.

Müller, J., Ruppert, H., Muramatsu, Y., Schneider, J., 2000. Reservoir sediments witness of mining and industrial development (Malter Reservoir, eastern Erzgebirge, Germany). Environ. Geol. 39, 1341-1351.

OPI, 2010. Observatoire des Professions de l'Image. <http://www.sipec.org statistiques.php?PAGE=statistiques $>$ (acceded in July 2010).

Páez-Osuna, F., Frias-Espericueta, M.G., Osuna-Lopez, J.I., 1995. Trace metal concentrations in relation to season and gonadal maturation in the oyste Crassostrea iridescens. Mar. Environ. Res. 40, 19-31.

Purcell, T.W., Peters, J.J., 1998. Sources of silver in the environment. Environ. Toxicol. Chem. 17, 539-546.

Reinfelder, J.R., Wang, W.-X., Luoma, S.N., Fisher, N.S., 1997. Assimilation efficiencies and turnover rates of trace elements in marine bivalves: a comparison of oysters, clams, and mussels. Mar. Biol. 129, 443-452.

Rivera-Duarte, I., Flegal, A.R., 1997. Pore-water silver concentration gradients and benthic fluxes from contaminated sediments of San Francisco Bay, California, USA. Mar. Chem. 56, 15-26.

Rivera-Duarte, I., Flegal, A.R., Sañudo-Wilhelmy, S.A., Véron, A.J., 1999. Silver in the far North Atlantic Ocean. Deep-Sea Res. Pt II 46, 979-990.

Roulier, J.-L., Belaud, S., Coquery, M., 2010. Comparison of dynamic mobilization of $\mathrm{Co}, \mathrm{Cd}$ and $\mathrm{Pb}$ in sediments using DGT and metal mobility assessed by sequential extraction. Chemosphere $79,839-843$.

Schäfer, J., Blanc, G., 2002. Relationship between ore deposits in river catchments and geochemistry of suspended particulate matter from six rivers in southwest France. Sci. Total Environ. 298, 103-118.

Schäfer, J., Blanc, G., Lapaquellerie, Y., Maillet, N., Maneux, E., Etcheber, H., 2002. Ten-year-observation of the Gironde tributary fluvial system: fluxes of suspended matter, particulate organic carbon and cadmium. Mar. Chem. 79 229-242.

Schäfer, J., Blanc, G., Audry, S., Cossa, D., Bossy, C., 2006. Mercury in the Lot-Garonne River system (France): sources, fluxes and anthropogenic component. Appl. Geochem. 21, 515-527.

Sottolichio, A., Castaing, P., 1999. A synthesis on seasonal dynamics of highly concentrated structures in the Gironde Estuary. C.R. Acad. Sci. II 329, 795-800

Tappin, A.D., Barriada, J.L., Braungardt, C.B., Evans, E.H., Patey, M.D., Achterberg, E.P., 2010. Dissolved silver in European estuarine and coastal waters. Water Res. 44, 4204-4216. 
Turner, A., Millward, G.E., Bale, A.J., Morris, A.W., 1993. Application of the KD concept to the study of trace metal removal and desorption during estuarine mixing. Estuar. Coast. Shelf Sci. 36, 1-13.

US EPA, 2001. Update of Ambient Water Quality Criteria for Cadmium 822-R-01001. US Environmental Protection Agency, Washington.

US PHS, 1990. Toxicological Profile for Silver. US Public Health Service, Agency for Toxic Substances and Disease Registry, Atlanta.

Valette-Silver, N.J., 1993. The use of sediment cores to reconstruct historical trends in contamination of estuarine and coastal sediments. Estuaries 16, 577-588.
Van Den Berg, G.A., Loch, J.P.G., Van Der Heijdt, L.M., Zwolsman, J.J.G., 1999. Mobilisation of heavy metals in contaminated sediments in the river Meuse, The Netherlands. Water Air Soil Pollut. 166, 567-586.

Vijayavel, K., Gopalakrishnan, S., Balasubramanian, M.P., 2007. Sublethal effect of silver and chromium in the green mussel Perna viridis with reference to alterations in oxygen uptake, filtration rate and membrane bound ATPase system as biomarkers. Chemosphere 69, 979-986.

Zoumis, T., Schmidt, A., Grigorova, L. Calmano, W., 2001. Contaminants in sediments: remobilisation and demobilisation. Sci. Total Environ. 266, 195-202. 